\title{
Effect of immunodeficiency and tumor marker expression on HIV-related diffuse large B-cell lymphoma prognosis
}

\author{
Michael J Silverberg ${ }^{1 *}$, Jonathan Said ${ }^{2}$, Hongbin D Zha ${ }^{3}$, Donald I Abrams ${ }^{2,4}$, Otoniel Martinez-Maza ${ }^{2}$, \\ Michelle McGuire ${ }^{3}$, Reina Haque ${ }^{3}$, Margaret $\mathrm{Chi}^{3}$, Lanfang $\mathrm{Xu}^{3}$, Brandon Castor ${ }^{2}$, Chun Chao ${ }^{3}$ \\ From 13th International Conference on Malignancies in AIDS and Other Acquired Immunodeficiencies \\ (ICMAOI) \\ Bethesda, MD, USA. 7-8 November 2011
}

\section{Background}

Several tumor markers may predict survival in HIV+ patients with diffuse large B-cell lymphoma (DLBCL). Here, we evaluate the association of immunodeficiency $(C D 4<200)$ on expression of prognostic tumor markers and survival.

\section{Methods}

HIV+ DLBCL cases diagnosed between 1996-2007 within Kaiser Permanente California were identified. H\&E slides were reviewed to identify representative tumor blocks for tissue microarray (TMA) construction. Immunohistochemistry staining of TMA cores was used to detect the expression of selected markers in the categories of (1) cell cycle regulators, (2) B-cell activators, (3) anti-apoptotic proteins, and (4) others, including Epstein Barr Virus (EBV). Percent of DLBCL cells with visible marker staining was scored on a scale from $0-4$ (i.e., $0-9 \%, 10-24 \%, 25-49 \%$, $50-74 \%$ and $\geq 75 \%$ ). EBV infection was determined by in situ hybridization of EBV RNA. We also considered high vs. low expression levels based on previously established cut-offs. Of the 20 markers previously examined, three had emerged as significant predictors of survival, including EBV, cMYC and BLIMP1. Here, we evaluated the association between $\mathrm{CD} 4$ and expression of these three markers by $\mathrm{t}$-test for mean levels and chi-square for $\%$ high levels. We also evaluated the combined effect of immunodeficiency and marker expression on 2-year survival in unadjusted Cox models.

\footnotetext{
* Correspondence: Michael.j.silverberg@kp.org

${ }^{1}$ Kaiser Permanente Northern California, Oakland, CA, USA

Full list of author information is available at the end of the article
}

\section{Results}

We identified 194 HIV+ DLBCL cases; 80 patients had adequate tissue for the marker analyses. Of the three markers, only EBV was associated with CD4 level (Table 1).

Survival was lowest in cases with high levels of EBV or cMYC in combination with low CD4 (Table 2). Survival was not evaluated for BLIMP1 given the low prevalence.

\section{Conclusion}

Immunodeficiency was associated with EBV+ DLBCL. Cases with low CD4 and high levels of EBV or cMYC had worse survival. Risk stratification may consider both CD4 and tumor marker expression, although confirmation is needed in larger studies.

Table 1 Tumor marker levels by CD4

\begin{tabular}{|c|c|c|c|c|c|c|c|c|c|}
\hline & \multicolumn{3}{|c|}{ EBV } & \multicolumn{3}{|c|}{ CMYC } & \multicolumn{3}{|c|}{ BLIMP1 } \\
\hline & \multicolumn{3}{|c|}{ CD4 } & \multicolumn{2}{|c|}{ CD4 } & \multicolumn{4}{|c|}{ CD4 } \\
\hline & $<200$ & $\geq 200$ & $P$ & $<200$ & $\geq 200$ & $P$ & $<200$ & $\geq 200$ & $P$ \\
\hline Mean levels & 1.9 & 0.6 & 0.009 & 1.6 & 1.7 & 0.90 & 0.3 & 0.2 & 0.65 \\
\hline $\begin{array}{c}\% \text { high } \\
\text { levels }\end{array}$ & 45.7 & 16.0 & 0.016 & 68.6 & 64.0 & 0.71 & 11.1 & 8.0 & 0.69 \\
\hline
\end{tabular}

Table 2 Two-year survival by CD4 and marker levels

\begin{tabular}{lcccccc}
\hline & \multicolumn{3}{c}{ EBV } & \multicolumn{5}{c}{ CMYC } \\
\hline & HR & $95 \%$ Cl & P & HR & $95 \%$ Cl & P \\
\hline Low CD4/high marker & 4.0 & $1.6-10.2$ & 0.004 & 3.3 & $1.0-11.5$ & 0.057 \\
Low CD4/low marker & 1.8 & $0.7-4.9$ & 0.236 & 1.0 & $0.2-4.8$ & 0.970 \\
High CD4/high marker & 1.6 & $0.3-7.7$ & 0.557 & 1.3 & $0.3-5.1$ & 0.739 \\
High CD4/low marker (ref) & 1.0 & - & - & 1.0 & - & - \\
\hline
\end{tabular}




\section{Author details}

${ }^{1}$ Kaiser Permanente Northern California, Oakland, CA, USA. ${ }^{2}$ University of California, Los Angeles School of Medicine, Los Angeles, CA, USA. ${ }^{3}$ Kaiser Permanente Southern California, Los Angeles, CA, USA. ${ }^{4}$ San Francisco General Hospital, San Francisco, CA, USA.

Published: 19 April 2012

doi:10.1186/1750-9378-7-S1-P47

Cite this article as: Silverberg et al:: Effect of immunodeficiency and tumor marker expression on HIV-related diffuse large B-cell lymphoma prognosis. Infectious Agents and Cancer 2012 7(Suppl 1):P47.

Submit your next manuscript to BioMed Central and take full advantage of:

- Convenient online submission

- Thorough peer review

- No space constraints or color figure charges

- Immediate publication on acceptance

- Inclusion in PubMed, CAS, Scopus and Google Scholar

- Research which is freely available for redistribution

Submit your manuscript at www.biomedcentral.com/submit 